This is an electronic reprint of the original article. This reprint may differ from the original in pagination and typographic detail.

Author(s): Lamberg, Juha-Antti; Laurila, Juha; Nokelainen, Tomi

Title: $\quad$ Institutional Path Dependence in Competitive Dynamics: The Case of Paper Industries in Finland and the USA

Year: $\quad 2017$

Version:

Please cite the original version:

Lamberg, J.-A., Laurila, J., \& Nokelainen, T. (2017). Institutional Path Dependence in Competitive Dynamics: The Case of Paper Industries in Finland and the USA.

Managerial and Decision Economics, 38(7), 971-991.

https://doi.org/10.1002/mde.2839

All material supplied via JYX is protected by copyright and other intellectual property rights, and duplication or sale of all or part of any of the repository collections is not permitted, except that material may be duplicated by you for your research use or educational purposes in electronic or print form. You must obtain permission for any other use. Electronic or print copies may not be offered, whether for sale or otherwise to anyone who is not an authorised user. 


\title{
Institutional Path Dependence in Competitive Dynamics: The Case of Paper Industries in Finland and the USA
}

\begin{abstract}
Prior research on competitive dynamics has failed to offer tools to understand distorted patterns of competition that emerge from distinct institutional and historical contexts. Our analysis suggests that a joint effect of institutional rules, governance structures, and shared cognition plays a pivotal role in firm-level competitive behavior and capability development. We show how globally significant market positions can result from specific institutional arrangements between firms and governments, especially if coupled with interfirm contractual commitments. Our results call for more attention to these interfirm commitments that are built on formal rules and governmental support, but whose impact they yet exceed.
\end{abstract}

Keywords: competitive dynamics, competitive strategy, new institutional economics, contractual commitments, shared cognition, history, forest industry.

\section{INTRODUCTION}

Strategic management research has advanced multiple perspectives on understanding competition, such as industrial organization (Porter, 1980), the resource-based view (Wernerfelt, 1984), the dynamic capabilities perspective (Teece, Pisano and Shuen, 1997), and competitive dynamics (Smith, Grimm, Gannon and Chen, 1991). The competitive dynamics perspective stands out from the others by viewing competition as interaction between rival organizations (Grimm et al., 2005). With individual competitive action as the elementary unit of analysis, a key question related to explaining organizations' competitive behaviors and the resulting outcomes asks how to understand the processes that generate such actions.

According to existing research on competitive dynamics, such action-generating processes involve not only managers' intentions and cognitions (Hambrick, Cho and Chen, 1996) but also the use of existing capabilities (Ndofor, Sirmon and He, 2011). These two elements are combined in the Awareness-Motivation-Capability (AMC) framework (Chen, Su and Tsai, 2007; Livengood and Reger, 2010), which the competitive dynamics tradition has widely adopted as the key theoretical 
perspective for theorizing about and predicting competitive behavior. According to the AMC framework, for an organization to initiate a competitive action, its decision-makers must first become aware of an opportunity for a particular action and then become motivated to undertake the action. Finally, the organization as a whole must have the capability to carry out the action. Although not all research on firms' competitive behavior explicitly employs the AMC framework, the vast majority shares the framework's key premises of managerial decision-making (A and $\mathrm{M}$ ) and organizational capabilities (C) driving competitive behavior and (eventually) competitive performance. The firmspecific nature of the AMC framework, however, has prevented competitive dynamics researchers from identifying alternative explanations for competitive behavior.

The alternative approach that we propose is rooted in new institutional economics that see any economic behavior as largely determined by prevailing institutional rules and governance structures (Williamson, 2000; Zenger, Lazzarini and Poppo, 2000). Despite some exceptions (e.g., Miller and Chen, 1996; Livengood and Reger, 2010), action-based literature on competitive strategy has treated competition as reacting to events in companies' immediate market surroundings, thus excluding the possibility that actions' premises could be interpreted to reflect the institutional environment in which firms are embedded (Granovetter 1985). The most salient exception to this dominant view is the recognition of behavioral conformity typical in an industry, with "continuation of traditions" and "industry experience" as contributing factors (Miller and Chen, 1996: 1209). Similarly, although some studies of competitive behavior have explicitly incorporated the national context in their investigation, they have viewed that context from the perspective of regulatory protection against competitive entries and the prevailing general availability of resources in the national economy (e.g., Meyer and Sinani, 2009). Overall, a more thorough integration of new institutional economics into the understanding of competition and firm-level competitive dynamics remains missing. 
New institutional economics (NIE) researchers have explicitly linked competitive interaction and the institutional environment in which such interactions occur. Mantzavinos, North, and Shariq (2004) view the interaction between institutions and competition as a crucial element in economic evolution:

"What kind of competition prevails during the process of exchange depends crucially on the institutions that prevail at the time. Institutions determine not only the kind of competitive game, but also its tempo. So the players' tempo of learning depends on the intensity of the competition, which is in turn set by the institutional framework. Because of competition, the agents suffering from pecuniary external effects are motivated to learn more to ensure their survival in the economic struggle."

Despite this relatively obvious link between competitive dynamics and NIE theorizing (cf. Denzau and North, 1994; Ingram and Silverman, 2000), most research on competitive strategy has not posited the surrounding institutional environment as an important condition for the phenomenon, instead treating signs of such influence as anomalies (e.g., Miller and Chen, 1996). In contrast, the purpose of our research is to offer an institutional explanation for historically contingent patterns of competitive behavior. We build our theorizing on a comparative setting in which we observe the competitive actions of two distinct groups of firms: one group (U.S. forest-industry firms) with firmspecific "strategy as choice" (Porter, 1996) behaviors that result in heterogeneity at the industry level, and another group (Finnish forest-industry firms) displaying mutually similar behaviors that result in group-level mimicry with respect to the industry as a whole. However, after a long rivalry between these very different groups, the global top-10 list of forest-industry firms contains firms from both of these groups. In line with Allen's (2011) and Langlois' (2013) works, the mystery that we want to solve is the following: which economic problems did Finnish forest-industry firms tackle by acting in concert and which types of features in their institutional environments explain their competitive behavior? We explain the rationale driving strategic decisions and capability development as interplays of path dependence (David 1994; Pierson 2000) on three levels: informal and formal institutions, governing structures of transacting, and shared cognition among an industrial elite. 


\section{THEORETICAL BACKGROUND}

\section{Situational Logic in Existing Competitive Dynamics Research}

Research in action-based competitive strategy is premised on studying what companies actually do and how they interact when they compete, with a specific discrete action as a basic unit of analysis (Smith et al., 1992). Along these lines, even if competition is not determined, it is at least strongly shaped by tension between companies, as perceived by their decision-makers (Chen et al., 2007), self-defined identity domains (Le Breton-Miller, Miller and Lester, 2011), and perceived competitive "turfs" that companies are especially motivated to defend, beyond the extent warranted by rationality (Livengood \& Reger, 2010).

Competitive dynamics research continues to lack nuanced theorizing about the connection between the process that drives competitive behavior and the institutional and historical contexts in which firm actions are embedded (Chen and Miller, 2012, p. 146). Consequently, the processual mechanisms underlying the identified associations between different variables remain largely implicit. According to Chen and Hambrick (2012), a viable path forward in this regard would be to build connections to institutionally oriented economic theory, which has well-established traditions that explain economic behavior as an inherently contextually embedded phenomenon. To date, despite the potential of this line of inquiry with respect to providing a theoretically solid foundation for bridging micro and macro phenomena in this area, institutional notions in action-based competitive strategy research essentially refer to behavioral patterns that conform to an industry's prevailing norm, i.e., "average" competitive behavior (Miller \& Chen, 1996; Podolny, 1993).

Thus, although it is well acknowledged both that competitive behavior is characteristically path dependent (Lamberg et al., 2009) and that competitive behavior defines a company in the eyes of its stakeholders (Parmar et al., 2010), who constantly judge the company and its legitimacy (Bitektine, 2011), very little is known about how the institutional environment is enacted by the company over time and how the company is reified and perceived by its stakeholders in turn (Chen 
and Miller, 2012). In particular, the competitive dynamics literature makes strong yet implicit assumptions of the rationalities that drive competitive actions, regardless of their historical and institutional context.

\section{New Institutional Economics Perspective on Firms' Competitive Behavior}

Whereas the competitive dynamics literature focuses on micro-level economic transactions and recognizes some connections between them and the surrounding institutional environment, a perspective informed by new institutional economics would turn this setting upside down. As indicated in our model illustrated in Figure 1, new institutional economists see competitive actions as “ $3^{\text {rd }}$ order economizing" (Williamson, 2000: 597) or "strategizing" (Williamson, 1991), which is determined by $1^{\text {st }}$ and $2^{\text {nd }}$ order economizing, that is, informal and formal institutions and governance structures. This positioning of competitive actions as a specific layer in a larger institutional system calls into question many of the explicit and implicit assumptions about decision-making criteria in the competitive dynamics literature and has a substantial potential to theoretically enrich that literature.

---- Figure 1 around here -----

Our model of the institutional process that leads to distinct patterns of competitive actions is particularly inspired by Williamson (2000: 597) and Denzau and North (1994: 18; see also Greif 1993; Greif and Laitin 2004). The model's key elements are competitive actions embedded in a specific institutional context and governance structure, on the one hand, and the restriction of these actions by the firms' capabilities to perform them on the other hand. Below, we further explicate our model and propose research questions that we then seek to address in the subsequent empirical analysis. 


\section{Managerial Cognition and the Exchange Problem}

The first difference between competitive dynamics and the NIE literature concerns rationality in general and the definition of an exchange problem in particular. In the competitive dynamics literature, the problem that drives firms to behave in certain ways in the marketplace is straightforward: the need to maximize short-term relative marketplace advantage over rivals competing over the same customer purchasing power (Williams, 2007). Usually the goal of such behavior is operationalized in terms of market share (Ketchen et al., 2004). On the one hand, firms' key goals are assumed to be minimization of adverse responses to their own actions. On the other hand, these goals are assumed to involve defending against one's own loss of market position in the face of threatening peer actions. Thus, the key trigger for competitive actions is the (implicitly motivated) maximization of a firm's share of customers' purchases and sometimes its ability to secure access to valuable resources (cf. Williamson, 1991).

The NIE literature takes a substantially different stance on rationality and managerial cognition. As Langlois (2013) summarizes in his review of Allen's book (2011), "rather than labeling puzzling behaviors as ignorant and inefficient... the NIE attempts to explain such puzzles as responses to the costs, constraints, and scarcities the economic actors face." Therefore, from the NIE perspective, organizational actors-entrepreneurs, managers, and others-observe and interpret the institutional environment and the contracts that guide actions and act accordingly (Ingram and Silverman, 2000). North and his colleagues (North, 1990; Denzau and North, 1997; Mantzavinos, North, and Shariq 2004) further emphasize the role of cognition and "mental models" (cf. Robertson and Langlois, 1994; Greif and Laitin 2004) as intra-firm mechanisms that make certain behaviors more viable than others. Mental models are "cognitive filters" in the sense that actors perceive elements in their institutional and contractual environment as related to economic transactions resulting in, for example, decisions on competitive behavior (cf. Langlois 1986: 241; North, 1990: 141 and 143). These works warrant particular attention on how managerial perception influences 
firm-level competitive actions and lead us to formulate our first research question. Research Question 1: How do aspects of the institutional environment, as perceived by managers in particular, materialize in firm-level competitive actions?

\section{Contractual Environment and Governance Structure}

The competitive dynamics literature pays little attention to the specific nature of firm governance structures. Firms' contractual environment is considered primarily a transactional space between mutually competing firms, their customers (Williams, 2007) and sometimes resource suppliers (Markman, Gianiodis and Buccholtz, 2009); individual studies focus on differences among firms (Chen and Hambrick, 1995; Ferrier, Smith and Grimm, 1999) and co-operative links between them (Gnyawali and Madhavan, 2001). For example, it has been found that implicit social contracts (i.e., shared understanding) (Yu, Subramaniam and Cannella, 2009) exist between rivals related to which markets "belong" to whom (and to what extent). The overall picture, however, remains centered on firms without explicitly including the contractual environment as a variable affecting their competitive behavior.

In contrast, the contractual nature of economic behavior is a key element in the NIE literature (Aoki, Gustafsson and Williamson, 1990). This is especially true of transaction cost economics (TCE) (Williamson 1985). Following Coase (1992) and especially Williamson (1975; 1985), many NIE scholars use contractual perspectives (Hart and Holmström 1986), not purely market-based transactions, to explain why firms exist (Argyres and Liebeskind, 2002). Williamson (e.g., 1991: 76) himself is very explicit in emphasizing the fundamental role played by contracts and the organizing of economic transactions (i.e., economizing) compared to strategizing (e.g., competitive actions). Consequently, firms are constrained in their competitive behavior. For example, all firms have made formal contracts with other firms and constituents (e.g., labor unions), and violating these contracts is often either impossible or very costly (Nickerson and Silverman, 2009). Simultaneously, the contractual environment both allows and motivates some actions. Williamson's (1991) example of 
the role of national governance system as a key factor underlying Japanese firms' commercial success since the Second World War is illuminating in this respect (cf. Mowery and Teece 1993; Teece 1992).

Thus, the key messages that TCE sends to competitive dynamics research can be condensed into two notions. First, firms are linked in various contractual ways to their environments (Ketokivi and Mahoney, 2016), and their internal governance structure strongly affects managerial decisionmaking (Hart 1995). Whereas TCE generally focuses on single transactions and contractual issues related to economizing these transactions, North (1990) and many management-oriented NIE scholars (e.g. Robertson and Langlois, 1994; Langlois and Foss 1999; Lazonick 1979; Teece 1992), along with Williamson (1991), treat firms' contractual environment as either a network (Granovetter, 1985) or a system (Hodgson 1998) in which firms are embedded. Second, governance structures are formed and maintained in specific historical contexts. According to Argyres and Liebeskind (1999), governance structures are sticky outcomes of past choices and might not be optimal when the context in which they were formed no longer prevails. Moreover, governance structures are particular because each economic commitment is tied to a specific set of stakeholders with heterogeneous interests. Although it would enhance efficiency to change one commitment, doing so would trigger a network-wide series of renegotiations with respect to other commitments, which in practice implies inertia (Aoki, Gustafsson and Williamson, 1990; Nickerson and Silverman, 2009). Taken together, if we take the overall message of the NIE literature seriously, we need to pay more attention to the period-specific effects that governance structures may have on firm-level competitive actions, which leads us to our second research question. 
Research Question 2: How does a firm's governance structure influence its competitive actions over time?

\section{Institutions: Both Informal and Formal}

Because of the sociological orientations of some of its key originators, competitive dynamics research has emphasized the internalized nature of institutions. Accordingly, competition is perceived as a game of market-performance maximization in which firms search for an appropriate behavioral profile that will not hurt their performance by violating social expectations (Shaffer, Quasney and Grimm 2000). In addition, firms might perceive a "typical behavioral style" as an industry norm and mimic that style to avoid "doing the wrong thing and suffering market performance losses" (Miller and Chen, 1996). It has also been commonplace for empirical studies to exclude variation in the institutional environment (e.g., deregulation or significant changes in the industry structure) during the research period to avoid "external sources of contamination" of the focal action data (see, e.g., Miller and Chen, 1996, p.425). Finally, Grimm and Smith (1997) noticed the potentially constraining effect of Antitrust Laws on large firm's competitive actions but to our knowledge this has not resulted in empirical research.

North (1990: 118) provides a clear contrast to the competitive dynamics research tradition in that he regards institutions as the "rules of the game"- devices that affect competitive behavior. As explicated by Williamson (2000), formal and informal rules are symbiotically related because the former (e.g., laws and regulations) build on the latter (e.g., norms and conventions). Accordingly, changes in any rule gradually transform the entire institutional system. However, this is not to say that it is commonplace for entrepreneurs to interpret the changing of rules as rational, but instead that rule-following is not predetermined even in contexts that contain strong rule-enforcing mechanisms (e.g., the state) (North, 1990: 73; Henisz and Delios, 2000). This recognition of an interpretative leeway among the actors involved with regard to the actions that they initiate encourages us to pose our third research question. Research Question 3: How does managerial actors' interpretation of the 
prevailing formal and informal institutions as either stable or susceptible to change influence competitive actions over time?

\section{Capabilities}

The competitive dynamics literature assumes that to carry out a particular action, a firm is required to possess specific capabilities (Chen et al., 2007). Moreover, in some studies, competitive actions also encompass firms' actions in the resource factor market, i.e., acquisitions of desirable capabilities (Markman et al., 2009). Typically, however, these capabilities are considered aggregates of various types of capabilities with no particular distinctions among them. Therefore, the competitive dynamics literature, for example, does not explicate a difference between technological and other capabilities. Usually, the only distinct capability is top management's cognitive capacity both to process (detect and interpret) information and to translate it into appropriate actions (e.g., Ferrier, 2001), although this ability is implicitly captured by the notions of awareness and motivation in the AMC framework and consequently is disconnected from "actual" capabilities (Chen, 1996). Accordingly, and with respect to the sources of competitive simplicity and inertia, for core competitive dynamics researchers a lack of capabilities is a sufficient cause for competitive inaction.

More generally, the largely accepted idea in the capability literature (e.g., Teece 2014) is that firms can either acquire new capabilities by developing skills and knowledge inside or seek complementary or new capabilities outside firm boundaries, for example, by conducting mergers and acquisitions. In both cases, the history of past decisions largely determines the universe of possible competitive actions (Winter, 2006; Page 2006).

Analogously to Schumpeter (1934), who considers technological change as a means for entrepreneurs to disrupt equilibrium, both North $(1990,78)$ and Williamson (1988) emphasize the role of technology and knowledge in how and why institutions change and affect economic behavior. Economies thus operate in a constant state of disequilibrium, as technological, political, social, regulatory, and other types of change offer a continuous supply of new information about different 
ways to use resources to enhance wealth (cf. Shane and Venkataraman 2000, 221). To supplement this perspective, other NIE scholars and evolutionary researchers (e.g., Langlois and Foss 1999; Lazonick 1979; Teece 1992) offer illuminating insights into the symbiotic role played by capabilities and institutions in the explanation of firm behaviors. The basic argument in these works is that the co-evolution of capabilities and institutions works in both directions. First, contractual commitments and institutions can enhance the effect of path-dependent (Page, 2006) routines and capabilities, thus inducing, for example, adaptation to major technological changes (Langlois and Robertson 1995). At the industry level, such inertia-enhancing institutions include protective regulation (North, 1990), educational policies (Langlois and Robertson, 1994), and public purchasing, all of which buffer firms (Gawande and Bandyopadhyay, 2000) from external competition and thus demotivate learning (cf. Repenning and Sterman, 2002). Second, some institutional designs may enhance learning. Japan (see Williamson, 1991; Teece, 1992), Israel (Breznitz 2007), and Ireland, for example, have been identified as well-functioning institutional environments for firm- and industry-level innovativeness. Murmann's studies $(2003 ; 2013)$ on the co-evolution of firm-level capabilities and government policies are important for our study because he offers a detailed account of the complex mechanisms that are necessary for obtaining competitive advantage in global competition. Together with the studies already mentioned, these works suggest that capabilities and institutions may operate as sources of both inertia and change in competitive behavior, which leads us to our fourth research question.

Research Question 4: How does capability evolution, as an interplay between firm-level actions and the institutional environment, affect the patterns of competitive actions over time? 


\section{EMPIRICAL ANALYSIS}

\section{Research Setting and Data}

The forest industry changed substantially during the period under study. These changes were brought about by globalization, new technological innovations, and the relative decline in demand for printing paper, which is the industry's traditional high-end market (cf. Ojala, Voutilainen and Lamberg, 2012; Klepper and Thompson, 2006; Ghosal and Nair-Reichert, 2009; Teece, 1982; Hetemäki, 2005). In our study, the forest industry functions as a natural experiment with five Finnish firms (Enso-Gutzeit, United Paper Mills [UPM], Metsäliitto, Kymi, and Serlachius ${ }^{1}$ ) whose competitive actions we first compare with four U.S.-based firms (Champion, International Paper, Mead, and Weyerhauser). The sample effectively represents a large portion of the largest firms in the global competitive setting. Additionally, the U.S. companies function as a control group to make the depth and nature of strategic change among the Finnish companies more apparent. In the latter part of our analysis, we provide an institutional explanation for the distinctive characteristics of the Finnish firms indicated by this comparison.

Our data collection process was divided into four phases that resulted in systematic datasets on the investment and divestment decisions made by the studied firms (see Table 1 below). Our data are different from the first wave of empirical competitive dynamics studies (e.g., Chen and Hambrick, 1995; Smith et al., 1991) in two respects. First, we have triangulated each identified action by using data from multiple sources. Second, because of its relatively low industry "clock speed" (Nadmarni and Narayanan, 2007), we studied the forest industry

\footnotetext{
${ }^{1}$ Enso-Gutzeit merged with Stora in 1998, forming Stora-Enso; Metsäliitto acquired Serlachius in 1986, forming first Metsä-Serla and later Metsä-Group; UPM and Kymi merged in 1995, forming UPM. We use the original names throughout the paper.
} 
over a long period, 1945-2000, and we therefore examined a reasonable number of strategic actions by each firm. The number of actions in the resulting database is 1,378 . The latter part of our analysis is based on a variety of archival data (cf. Kipping et al. 2014; Üsdiken and Kipping, 2014) that are contemporaneous with the competitive actions in our database. These materials contain tens of thousands of pages, have a strong in-situ flavor, and have not been manipulated by biased recollection or organizational storytelling (cf. Bingham and Kahl, 2013; David, Sine and Haveman, 2013). Moreover, we also have complementary material, as defined in Table 1.

---insert Table 1 around here-

In our analyses, we first visualized the competitive behavior of the studied companies. The comparison is illustrated by a principal component analysis (PCA) in which a 22dimensional variable space populated by companies' competitive actions was projected onto a two-dimensional plane to graphically illustrate the temporal development of the companies' competitive behaviors at a one-year resolution (see Appendix). The latter part of the analysis constitutes an in-depth, historical case study (cf. Jacobides, 2005) that is intended to produce an institutional explanation for the distinctive behavioral characteristics revealed by the PCA. Our analysis incorporated a classic approach to historical data (Carr and Davies, 1961; Collingwood, 1946) focused on the qualitative interpretation of competitive actions that can be traced and reconstructed using multiple data items to verify the trustworthiness of the researcher's interpretation (Bryant, 1994; Mahoney, Kimball and Koivu 2009; Vaara and Lamberg, 2016). Finally, in the spirit of non-linear constant theorizing (Martin 2014), we continued the iteration between data collection and interpretation until we could recognize plausible causal mechanisms behind the observed patterns of competitive behavior.

\section{The Competitive Behaviors of Finnish and U.S.-based Firms}


We start the two-folded presentation of findings by reporting the results of the PCA analysis on the competitive actions of Finnish and U.S.-based firms (see Figure 2 below). The immediate observation from the PCA illustration is that the two groups of companies differed considerably during the period under study. First, the U.S.-based firms were more active in changing their competitive behavioral directions and postures, whereas their Finnish competitors performed fewer actions, and the proportion of radical actions was also lower. Because travel to the right in Figure 2 is characterized by the dominance of investments over divestments (and vice versa), this result also implies that the U.S.-based firms were more expansive than the Finnish-based firms. In other words, even though all of the companies pursued a general strategy of expansion, the U.S.-based companies did so to a greater extent and in a wider variety of business areas. Moreover, the paths of the Finnish companies point in roughly the same general direction along the first principal component axis in Figure 2, indicating similar patterns of competitive behavior.

Insert Figure 2 here

Second, whereas the Finnish-based firms were relatively similar to each other in their behavioral styles, the companies with U.S. origins were characterized by significant differences in their behavioral paths. International Paper and Mead traveled largely together toward the upper righthand corner of Figure 2, and Weyerhaeuser traveled to the lower right-hand corner. Champion's path was aligned along the first principal component axis, especially from the 1940s to the 1980s and again from 1990 onward, suggesting a conservative behavioral pattern similar to that of the Finnish companies. The paths of the U.S. companies progressively diverged from each other over the study period, indicating the presence of qualitatively different behavioral patterns - and more radical strategic changes—over that period (cf. Toivanen, 2004; Ahola, 2006). 
The most salient observation from the PCA analysis is that all of the studied companies followed a relatively consistent internal path throughout the study period, with the exception of Champion from 1980 to 1990. Overall, Finnish companies manifested higher behavioral consistency than did their US counterparts. The results suggest that although the forest industry experienced an overall globalization process in terms of the increasing importance of supra-national service providers, shared production standards, and close connections among companies, Finnish companies were systematically more inert than U.S. companies in their competitive strategy. Moreover, the PCA analysis demonstrates strong similarities among the Finnish companies, whereas the large U.S. firms tended to adopt more firm-specific strategic postures. The comparison with U.S. companies and the relative inertia in terms of changing strategic direction within the context of globalization and an increasingly dynamic business environment call for a theoretically informed historical explanation that is especially sensitive to the institutional environment in which the firms are embedded. Accordingly, the next sections offer a historically informed institutional explanation for the distinctive patterns of Finnish firms' competitive behavior that was especially characterized by internal conformity and simplicity across the period under study. Table 2 presents an overview of the process.

--- insert Table 2 around here ---

\section{Institutional Environment}

In our research framework, the institutional environment of firms consists of three elements: embedding informal institutions, formal institutional rules and governing structures of transacting. These three elements then constitute the basis of managerial decision-makers' cognition, which then materializes in the actions that they initiate. Finally, the actions conducted moderate the capability base, which then influences the viability of different types of future actions. Because we have already depicted the competitive actions of the Finnish forest-industry firms, in this section we 
analyze the other elements in our framework in four subsequent sub-sections. In its entirety, the analysis aims to address the sources and mechanisms behind the substantial stability and lack of cross-organizational diversity in the competitive behavior of Finnish firms during our period of study.

\section{The Rules of the Game}

Whereas most economists would consider firms as adapting to prevailing institutions, in Finland the economic importance of the forest industry was such that many institutional arrangements were planned to promote instead of constrain its evolution. Simply put, it is difficult to overstate the historically and geographically grounded reasons for the prominence of the forest industry in Finland's economy and society (Moen and Lilja, 2001; Kuisma, 2008). Although Finland's first forest-industry production units and companies were founded relatively late-during the 1840 s and 1850s — by the First World War, the industry had already established its position as the country's most important industrial sector. In the beginning, most of the product output was exported to the closely located Russian markets. After the initial years of Finland's independence (1918-1921), forest industry in the form of pulp and paper production became the predominant export industry, representing nearly $80 \%$ of Finnish exports. From the 1920 s to the 1950 s, the forest industry's flagship position was further strengthened through substantial national-level support with respect to foreign trade and educational arrangements (Ahvenainen, 1984; Heikkinen, 2000; Peterson, 2001; Järvinen et al., 2009).

The forest industry was truly under the special protection of the Finnish government. As an example of this national-level support, the primary target in all of Finland's trade agreement negotiations, including the European Free Trade Association (EFTA) and European Economic Community (EEC) in 1960 and 1973, respectively, was to secure the forest industry's competitive position in its main export markets (Jensen-Eriksen, 2007a). Additionally, until its 1995 EU membership, the Finnish government never questioned the legal status of the industry's sales and 
purchasing cartels (Schröter 1996) and self-regulation (e.g., Jensen-Eriksen and Ojala 2015). With respect to education policy, Finnish government systematically considered the forest industry's interests in building the national educational and academic system. For example, the industry's R\&D activities were strongly promoted both financially by public agencies and culturally by presenting the forest industry in a form that would appeal to investors, researchers, and business and engineering graduates alike (Nykänen and Paulapuro, 2005). Taken together, the forest industry enjoyed a privileged position in the Finnish institutional system in both the formal and informal sense throughout the $20^{\text {th }}$ century. This also implied that little national institutional pressure would have indicated a need for individual firms to change their modus operandi. Moreover, the signals that were given were formulated as if one recipe would meet the needs of all firms. This approach is manifested in a report by the Ministry of Trade and Commerce, in which government authorities explicitly encouraged Finnish forest-industry firms to focus on their existing competencies, on the one hand, and to internationalize, on the other hand:

\footnotetext{
"If Finland wants to maintain its position as a leading forest industry producer and avoid being a marginal player in the value chain, internationalization is not an option but is mandatory. Only by aiming for international operations can we use the opportunities that our know-how offers." (Scenario prepared by Jaakko Pöyry for the Ministry of Trade and Commerce, 1979: 33)
}

\section{Governance Structure}

The governance structure of the Finnish forest industry was strikingly similar to how Williamson (1990) describes Japanese industries: efficient and systemic management of contractual relations supported and incentivized by the government and formal institutions. It was also in line with Chandler's (1990: 398) description of financial capitalism, in which "large multipurpose banks played a major role in providing funds...to achieve the economies of scale and scope... the representatives of banks sat on the boards of many enterprises, and so participated in [their] top-level decisions." Similarly, most Finnish forest-industry firms were controlled by one or two major commercial banks or were owned by the Finnish state (cf. Williamson, 1991: 89), which had a 
concrete impact on the commitments that the firms and their executives perceived. For instance, the strategic mission of the state-owned Enso-Gutzeit was to be profitable, although not at the expense of its relatively ambiguous "social responsibilities." In contrast, its close bank-controlled competitors Kymi and UPM operated as "normal" for-profit firms but were nonetheless involved in hegemonic struggles between the financial spheres under these banks. As a result, the Finnish firms had considerable leeway to develop their operations as long as they did not encounter severe profitability problems and/or disturb their network of commitments (Argyres and Liebeskind, 1999). As many of these corporatist governance practices had diffused to Finland from Germany in the late 19th and early 20th centuries (Moen and Lilja, 2001), it was not until the 1980s and 1990s that Finnish firms started to converge with the increasingly dominant U.S.-based firms (Kuisma, 2008). Consequently, these interfirm governance solutions and contractual systems also largely explain why Finnish forestindustry firms manifested strong similarities in their competitive behavior during the period under study.

The industry-level contractual arrangements for several important managerial functions can be considered an important source of conformity in the developmental strategic trajectories of Finnish forest-industry firms. Here, we may recognize four important arrangements. First, at the beginning of the $20^{\text {th }}$ century, most firms were relatively small, and it was difficult for them to handle contacts with the international markets on their own. This resulted in sales-cartel arrangements that continued from the early 1920s until the mid-1990s (Jensen-Eriksen, 2007b; 2011). Finnish law allowed these cartels, each of which focused on selling a specific product segment to the international markets (see, e.g., Eloranta et al., 2005; Jensen-Eriksen 2007a) and thus provided significant economies of scale, at least as far as the cost of market operations is concerned. However, there was also a significant downside to this arrangement. For example, the largest cartel, Finnpap, had defined which of its member companies were to produce particular paper grades, and the member companies' main task was to meet the cartel's expectations and quality criteria instead 
of having direct relationships with the customers and learning about those customers' preferences without middlemen (Heikkinen, 2000).

With respect to the second contractual 'buy rather than make' arrangement, since the early decades of the $20^{\text {th }}$ century, Finnish companies outsourced their R\&D activities to a jointly owned unit called KCL (Levlin, 2010). This implies that a substantial proportion of Finland's productdevelopment efforts were coordinated across individual firms, which had little proprietary knowledge that could have been turned into idiosyncratic products. Third, in addition to the fact that most of the top managers of Finnish forest-industry firms during our period of study were paper engineers by training, most had also graduated from the same academic department at the Helsinki University of Technology (Nykänen and Paulapuro, 2005). Thus, the engineers heading the individual companies typically knew each other personally and had little incentive to break away from the tight network of paper engineers. This similarity in educational background and belonging to an 'inner circle' implies homogeneity in the cognitive schemas with which environmental changes were monitored, interpreted, and acted upon. For example, when following their U.S.-based competitors, the engineers systematically concentrated on technical instead of strategic issues (Alajoutsijärvi, 1996; Nykänen and Paulapuro, 2005). Fourth, the Finnish firms' most innovative actions during the period of study were conducted jointly by several of them; those actions then operated as an additional force homogenizing their strategic behavior. For example, whereas in the 1960s the acquisition of Nordland Papier in Germany was a joint venture of two firms, the construction of a Eurocan pulp mill in Canada was a joint venture of five Finnish firms. It is important to note that a document that justifies the latter venture also refers to the general Finnish interests involved: the contractual commitments were exhaustive and not primarily based on economic calculations.

"Eurocan Pulp and Paper Co Ltd has been founded by Enso-Gutzeit Corporation, Myllykoski Paper Mill, Kymi Ltd, and Tampella Ltd together with Canadian entrepreneurs [...] The new joint operation aims to support competitiveness in the traditional international markets [for Finnish firms]. Simultaneously, the project offers export opportunities for the domestic metal industries.” (Internal Memo, Kymi Corporation, 1965) 


\section{Decision-Makers' Cognitive Interpretation of the Environment}

Engineer-dominated management and the absence of strong stakeholders that could have challenged the engineers' worldview largely explain the stability with which the various types of tangible changes in the firms' competitive environment were interpreted. We can consider two indications of this observation from the period of study. First, by the end of the 1970s, Finnish forest-industry firms had already grown to the extent that further growth opportunities had to be sought primarily from the international markets and as the following quotations show, internationalization as an opportunity for further growth was clearly on the management agenda.

"...it is obvious that growth and profitability in the future depend on the increasing importance of international markets.” (Strategy document, Kymi Corporation, 1982)

"[The] paper industry in the year 2000 will consist of a few conglomerates that have specialized units and [a] systematically managed investment policy." (Paper and Timber, 1984 (4), 500)

"The main business areas of Enso....are so large that they can only compete and expand based on the worldwide market and production." (Minutes of the meeting of the Enso board of directors, December 15, 1988)

At the same time, however, these firms' management regarded the industry's increasing internationalization more as a threat than as an opportunity. For example, by the early 1960s the Finns were already stunned by the acquisitions made by the U.S.-based firms in Europe, which the former had considered their exclusive territory. This development encouraged the Finns both to initiate similar types of acquisitions and to join forces for major international greenfield projects. Against the background of these mimetic responses, we note that from the 1940s onward, the Finnish firms had very consciously begun to engage in direct imitation of the production-related knowledge of their most advanced competitors, which at the time were deemed primarily to reside in the U.S. For example, Finnish paper-industry students and engineers visited North American mills until they realized that they themselves, along with related Finnish machine industries, had reached equal or superior levels of engineering. As a senior executive recalled in an interview:

"It was a common practice to travel to the U.S. for shorter and longer periods of time...U.S. firms were very open; they showed us everything, and we copied all the best practices. Then, in the 1960s and the 1970s, there was a general understanding that we [Finnish paper engineers] no longer had anything to learn from U.S. firms." (former UPM executive) 
Second, the stability of interpretation also materialized in the overwhelming production orientation with which the Finnish firms responded to constant industry-level changes. For example, they recognized a need to expand their companies and individual production units with the help of new technology. However, these expansions mostly concentrated on escalating current activities instead of attempting to radically reposition them in ways that would open up new industry-level avenues, which implied a totally different positioning than the one that, for example, the big U.S. forest-industry firms had adopted. This implied that the Finnish firms mostly focused on efficiency and process innovations. This was the case even when the firms' management claimed to be marketoriented, as the quotations below indicate:

\begin{abstract}
"The corporation has decided to focus on the service business. Therefore, the whole organization needs to adopt a market-oriented attitude that emphasizes the satisfaction and needs of customers. With this strategy, it is possible to (a) gain market shares in the publishing paper market, (b) be a leading firm in the efficient use of paper machines, (c) improve productivity in chemical paper making, and (d) build a very competitive paper mill integrated in Kuusankoski and Voikkaa [two neighboring paper mills in the southeastern part of Finland]." (Strategy Document, Kymi Corporation, 1985)
\end{abstract}

"Since 2001, we have made big changes in... our European mills. We have closed pulp mills and four paper machines and, in addition, restructured our mechanical forest industry operations. This is not the first time the company has changed, yet this turbulence is so intense and so fast that we had to react more forcefully." (Interview of UPM CEO Jussi Pesonen, Talouselämä, 12.5.2006)

In addition, all aspects not under the direct company control, such as the provision of raw materials, appeared as an unpleasant dependency upon external actors. Even the above-mentioned major cross-Atlantic Greenfield endeavor was motivated more as a way to remove then-present resource constraints than to enter new end-product markets. The quotation below illustrates this reasoning:

“... because of constantly increasing production costs and a fear of insufficient raw materials, Enso-Gutzeit Corporation has explored opportunities to expand production and serve customers better in more suitable environments...over the past decade, British, German, Belgian, Italian, Danish, and Swedish companies focused their attention on new sources of raw materials. It is natural that our country cannot ignore this rapid international development.” (Internal memo, Enso-Gutzeit Corporation, 24.5.1965)

When we combine these two examples with the notion that the Finnish firms' management clearly constructed themselves as a group with joint interests and did not pay attention to diversity 
among the strategies of their foreign peers, it is possible to understand the conformity and relative simplicity of these firms' competitive behaviors. In part, the apparently similar cognitive schemas of the management of individual firms also led them to interpret competitive conditions analogously. For example, when the consulting group Jaakko Pöyry, the main consultancy firm in the field of market forecasting and technical planning, predicted in the 1980s that the forest industry would not be threatened by the progressing changes in communication, the message quoted below raised no suspicions among the Finnish firms. This suggests that the heads of the Finnish companies were more eager to obtain support for an idea of status quo than for an idea of upheaval. Simultaneously, it is possible to rule out the Finnish managers' unawareness of their foreign competitors, the increasingly international nature of competition and the ongoing changes in the industry as an explanation for the observed patterns of competitive behavior.

"Communication by means of information printed on paper will persist in the electronic age simply because it works and works well in most situations. The new technologies will introduce new possibilities of communication that will both enhance and in some cases substitute for paper. The trend is, however, toward more paper being consumed rather than less. Books, magazines, and newspapers will retain their unique and widely appreciated qualities." (Rennel, 1984: 227)

\section{Capabilities as Enabling and Restricting Available Actions}

The production-centered actions performed by the Finnish forest-industry firms during the period of study also influenced the nature and evolution of the capability base that operated as a platform for further actions. Although their competitive actions gradually provided the Finnish firms with the highest production efficiency, those same actions restricted their ability to initiate other types of actions. This characteristic was further enhanced by the fact that many functions with no direct connection to production were conducted through various industry-level joint arrangements, which then prevented firm-level capability extensions in these areas. Consequently, and as the quotation below indicates, the overall industry was considered something that only engineers could manage:

"Production capacity in the paper industry has reached a saturation point. Automation has proceeded quickly, and because of that, firms do not need more engineers than are educated at the moment. The only stimuli for possible scaling up of engineering education are the higher integration rate of production facilities and the renovation and closing of old production facilities. (Report by Keijo Mäkelä, DIAKTA 1980-project, 1980).” 
Furthermore, because most of the important innovative actions by the Finnish firms were conducted collectively, they extended the previous capability base similarly across individual companies, further blocking opportunities for company-specific strategic openings. The increasing drift toward focused companies reinforced this pattern. For example, whereas many Finnish forestindustry firms (e.g., Enso-Gutzeit) operated in a multi-divisional form until the late 1970s, divestments away from areas not directly related to paper and pulp began soon thereafter (e.g., Ahvenainen, 1992) merely because all available assets were required to be invested to obtain enhanced productivity in the core business (Järvinen et al., 2012) and to satisfy the assumed international capital markets' demands for focused companies. As a result, mergers between Finnish forest-industry firms became common. The excerpts below illustrate these aspects.

\footnotetext{
"Kymi Corporation must continue producing certain products simply because of the existing machinery and raw material solutions. We cannot make dramatic changes without heavy investments, yet the current product portfolio and strategy allow competitiveness in international markets. Therefore, it is of crucial importance to constantly improve our production efficiency, make focused and well-planned investments, and concentrate on knowing our customers' needs." (Strategic Vision, Kymi Corporation, 1985)

"Intensive international competition calls for efficient, fully integrated paper mills. Mergers between existing producers enable this kind of development." (CEO Speech, Kymi Corporation, 1986)
}

Inevitably, individual firms' opportunities to make idiosyncratic innovations were severely constrained by their commitments to the above-mentioned joint bodies of marketing and R\&D. As an example of the former, the Finnish firms' strong emphasis in printing-paper grades was partly an outcome of Finnpap having signaled continuous growth in those grades and its failure to offer alternatives (cf. Heikkinen, 2000). Although some of the largest firms (e.g., Enso and Kymi) had established their own marketing departments in the 1980s, for the other firms in these circumstances it was easiest to stick to their knitting and satisfy the defined needs as cost-efficiently as possible (Järvinen and Linnakangas 2012). This characteristic was further enhanced during times of international recession or various resource shortages caused by unsuccessful international endeavors (Peterson, 2001; Kuisma, 2008). The negative effects of the joint R\&D arrangements on the Finnish forest industry's capability base materialized in several indicators (see Peltoniemi 2013). These 
indicators suggest that before 2000, the industry was characterized by (a) a narrow patent portfolio; (b) a narrow technological focus on "giant machines" that could efficiently produce paper but were relatively useless for other purposes; (c) a lack of sponsorship of academic research activities aimed at developing alternative uses of wood materials; and (d) an extremely specialized corporate structure (compared with, for example, that of U.S. firms) (see Appendix). The reasoning underlying this overall pattern is illustrated in the quotation below.

“The future is always challenging. For example, the growing up of the so-called ' 2 nd television generation' in the 1990s may change the market entirely, as they are used to receiving information from a screen [...] It seems obvious that only large fully integrated mills will survive, whereas the small, the old, and the weak must die." (Strategy Document, Kymi Corporation, 1985)

\section{DISCUSSION AND CONCLUSIONS}

The motivation for our study was to enrich and develop the current theoretical understanding of competitive dynamics. Overall, our study constitutes a step toward a detailed analysis of the mechanisms that convert environmental stimuli into firm-level competitive actions. Our results unambiguously suggest that competitive dynamics—including both rivalry itself and the interplay of organizational processes and competitive interaction-is a substantially more nuanced and complex phenomenon than the extant competitive strategy literature (e.g., Ketchen et al., 2004; Porter 2008) has depicted. In particular, our results seriously call into question the prevailing view in the competitive dynamics literature according to which competitive behavior primarily represents reactions to new events and pieces of information in companies' immediate market surroundings in the interest of achieving or defending market positions (cf. Williams, 2007).

Our empirical study and the resulting theoretical insights emphasize that both the emergence and evolution of competitive strategies are deeply embedded in specific institutional and historical contexts (Granovetter 1985; Zenger, Lazzarini and Poppo, 2000). This is caused not only by insufficient management capabilities and difficulties in recognizing a firm's competitive position (c.f. Chen et al., 2007) but also by the prevailing "rules of the game" and governance structures that enforce firms' adherence to diverse contractual commitments (Argyres and Liebeskind, 1999; Aoki, 
Gustafsson and Williamson, 1990). Our study shows that the aspects of the institutional environment, especially as perceived by managers, substantially influence firm-level competitive actions and that those formal and informal institutions that management interprets as stable then largely define how it allocates its attention when considering new actions (cf. Henisz and Delios, 2000). Additionally, our cross-comparative analyses of the Finnish and U.S. paper industries suggest that the evolution of firms' capability base and institutional environment are closely related to each other. In the case of Finland, this relation materialized in the overall privileges enabled by the state for this industry in general, but even more importantly in its allowance of intra-industry joint investment, marketing and R\&D operations, which then restricted or even prevented certain courses of action. In contrast, the firm-centric R\&D philosophy in the U.S. combined with more distinct strategic profiles allowed more radical changes in product offerings and competitive action patterns (cf. Toivanen, 2012; Ahola, 2006). In line with Toivanen (2004), we do not exclude the influence of U.S. industrial governance arrangements on the technological trajectories of its paper industry; however, we argue that these arrangements were much more subtle by nature than what was the case in Finland.

In a theoretical sense, our study extends and challenges the previous competitive dynamics literature. The unique features and strengths of this research stream have been its narrow focus on the interchange of competitive actions between rival firms (Chen and Miller, 2012), through which it has laid a foundation for the understanding of micro-level market competition. However, the focus on competitive actions and the processes preceding the launch of these actions (Chen et al., 2007) has resulted in strong emphasis on top management team qualities and decision-making effectiveness (Ferrier and Lyon, 2004). In contrast to this "agentic" perspective, which views competitive behavior as "jockeying... that sabotages [a] rival's profits" (Ketchen et al., 2004: 780), our findings suggest that competitive behavior is strongly influenced by the company's institutional surroundings and prior behaviors. That is not to say that managers would not be important but instead that managers 
are not merely market advantage-maximizing information processors (Smith et al., 1991): their role and intentions are embedded in and therefore to a large degree are determined by particular institutional environments. As in our empirical case, the Finnish firms came to be seen as constituting a national "flagship" industry that was practically an informal institution in and of itself (Lamberg and Laurila, 2005; Laurila and Ropponen 2003). Such an institutionally strong position (cf. George et al., 2006), especially when conjoined with national pride (Hope, Thomas and Vyas 2011), did not provide any significant motivation to alter the firms' behavioral posture. Instead, it served as a reinforcing mechanism (Sydow, Schreyögg and Koch 2009) to continue along an established strategic trajectory. However, to enact and thereby further solidify the institutional position, in contrast to jockeying for firm-specific market advantage, the firms expanded their geographical scope and business volume. In this light, the focal companies' competitive trajectories, as depicted in Figure 2, are entirely understandable when set alongside the essential elements of the surrounding institutional environment and governance structures. These characteristics of the institutional environment also had an impact on the individual managers, who were primarily (a) a homogenous and tightly linked group of paper engineers; and (b) who felt personal responsibility not only for the profitability of the companies that they headed but also for the economic and political development of Finnish society. Overall, the small size of the Finnish economy and the tightness of its industrial elite encouraged intra-industrial conformity. In contrast, international comparisons (Crossland and Hambrick 2011; Quigley and Hambrick 2015) demonstrate that the U.S. corporate culture encouraged a higher degree of risk taking, CEO autonomy, and more radical changes in competitive positions.

Moreover, our findings suggest that in the institutional environment in which the company is embedded (Granovetter 1985), the initiation of competitive actions is constrained by an institutional matrix (North, 1990) that determines "how things are" and "how one should behave" (Beckert, 1999; Miller and Prentice, 1996), which significantly exceeds the adopting behavior typical of an industry 
that fears adverse market performance (Chen and Hambrick, 1995). Because a firm is also an entrepreneurial actor in this institutional environment, there are expectations of conformity to prevailing norms and consequently, any departure from those norms requires extra effort and creates the risk of sanctions attributable to the loss of legitimacy (Suchman, 1995; Nickerson and Silverman, 2009). On the institutional level, the most salient firms experience the greatest pressures. In our study, the focal firms were societally established and therefore were subject to highly significant expectations related to their predictability that discouraged them from engaging in exploring new competitive postures. The stickiness of competitive behavior also regresses to the largest firms' contractual commitments. These commitments and the governance structure of the industry as a whole further strengthened the weight of formal institutions, allowing some forms of collaboration and prohibiting some forms of competition. As an example of the latter, Finnish universities were not allowed to increase their intake of students specializing in the forest industry, which could have potentially increased the strategic diversity among firms.

Our study also contributes to the previous research on strategy that takes the new institutional economics research as its starting point (see Zenger, Lazzarini, and Poppo, 2000). Ever since the pioneering works by Williamson (1975) and North and Thomas (1973), the NIE perspective has continued to inspire strategy research in international business (Cantwell, Dunning and Lundan, 2010; Meyer, 2005), corporate political activity (Ville, 2007), diversification (O'Brien et al., 2014) and other areas. However, within this stream studies on the micro-foundations of institutional inertia and change remain rare. The primary reason for this failure to scrutinize firm-level activities could be the theoretical assumption of the marginality of $4^{\text {th }}$-order interventions on higher-order institutional order. For example, on several occasions, North (1990: 104; Mantzavinos, North, and Shariq, 2004) has underlined the importance of entrepreneurial activities as a source of institutional change; however, his theorizing has stopped short at the question of "how" entrepreneurs create this change. 
As a response to this void, our study brings new evidence of the complexity related to those patterns of firms' competitive behavior that catalyze institutional inertia and change. The history of Finnish forest-industry firms' competitive actions reveals both the ubiquitous nature of institutions and governance structures as stabilizing forces in the evolution of this industry and the role of distinctive firm-level actions and capability development paths as triggers for institutional change (Henisz and Delios, 2000). In retrospect, it is possible to identify the main characteristics of this system lock-in, resulting in strong group thinking and an extremely narrow, long-lasting perception of how the industry should strategically operate. However, the complexity inherent in those "entrepreneurial" actions (North, 1990) that did yield institutional change is theoretically illuminating. For example, our study addresses the abandonment of the sales cartels that the Finnish firms applied for more than 70 years until the arrangement was banned when Finland joined the European Union in 1995. At the surface level, this change in the formal rules seems a necessary and sufficient cause for the abandonment of sales cartels. A detailed analysis of the pre-abandonment process that began in the late 1970s, however, reveals much more nuanced dynamics underlying this event. These dynamics include (a) forest industry associations' proactive lobbying for Finland to join the European Union (Kuisma, 2008) despite the latter's well-known hostility toward cartels; (b) friction among the largest firms about how to proceed with sales collaboration; and (c) the Kymi and Enso-Gutzeit corporations' activities during the 1980s to develop the ability to operate without cartels. Finally, (d) when UPM revealed to public authorities a purchasing cartel in which it was one of the key actors, the resulting conflict also meant the end of collaboration in research and development and other traditional forms of cooperation among the Finnish firms. Taken together, the process resulted in the end of one contractual commitment among the firms involved a complex web of causalities in which firms' actions and capability development played a major role. This analysis in which firm-level contractual commitments and formal institutions are intertwined is all but absent in Williamson's framework (2000). However, our findings suggest that there may be cross-firm 
coordination and an industry culture that is closer to governance than the formal institutions in

Williamson's framework. This further emphasizes the importance of paying continued attention to

the micro-foundational level of institutional change (cf. Zenger et al, 2001) and the connection

between micro- and macro-levels of analysis in general (Granovetter 1973) in future research.

\section{REFERENCES}

Ahola A. (2006). Comparing strategic evolution of Weyerhaeuser, Georgia-Pacific and Mead. In The Evolution of Competitive Strategies in Global Forestry Industries: Comparative Perspectives, Lamberg J.-A., Näsi J., Ojala J., Sajasalo P. (eds). Amsterdam: Springer, 65-105.

Ahvenainen J. (1984). Suomen Sahateollisuuden Historia. Helsinki: WSOY.

Ahvenainen, J. (1992). Enso-Gutzeit Oy 1872-1992. Imatra: Enso-Gutzeit.

Alajoutsijärvi, K. (1996). Rautainen Pari: Kymmenen ja Valmetin Suhde, Lähiverkosto ja Makrovoimat 1948-90. Doctoral dissertation. Jyväskylä: University of Jyväskylä.

Allen, D. W. (2011). The Institutional Revolution: Measurement and the Economic Emergence of the Modern World: University of Chicago Press.

Aoki, M., Gustafsson, B., and Williamson, O. E. (1990). The Firm as a Nexus of Treaties. London: SAGE.

Argyres, N. S., and Liebeskind, J. P. (1999). Contractual commitments, bargaining power, and governance inseparability: Incorporating history into transaction cost theory. Academy of Management Review, 24(1), 49-63.

Beckert, J. (1999). Agency, entrepreneurs, and institutional change: The role of strategic choice and institutionalized practices in organizations. Organization Studies, 20 (5), 777-799.

Bingham, C. B., and Kahl, S. J. (2013). The Process of schema emergence: Assimilation, deconstruction, utilization and the plurality of analogies. Academy of Management Journal, 56(1), 14-34.

Bitektine A. (2011). Toward a theory of social judgments of organizations: The case of legitimacy, reputation, and status. Academy of Management Review, 36(1), 151-179.

Boyd, J. L., and Bresser, R. K. F. (2008). Performance implications of delayed competitive responses: Evidence from the U.S. retail industry. Strategic Management Journal, 29(10): 1077-1096.

Breznitz, D. (2007). Innovation and the State: Yale University Press.

Bryant, J. M. (1994). Evidence and explanation in history and sociology: critical reflections on Goldthorpe's critique of historical sociology. British Journal of Sociology, 45(1), 3-19.

Cantwell, J., Dunning, J. H., \& Lundan, S. M. (2010). An evolutionary approach to understanding international business activity: The co-evolution of MNEs and the institutional environment. Journal of International Business Studies, 41(4), 567-586.

Carr, E. H., and Davies, R. W., (1961). What is history? Oxford University Press, Oxford..

Chandler, A. D. (1990). Scale and Scope: The Dynamics of Industrial Capitalism. Cambridge: Harvard University Press.

Chen M.-J., and Miller D. (2012). Competitive dynamics: Themes, trends, and a prospective research platform. Academy of Management Annals, 6(1), 135-210.

Chen, M.-J., and Hambrick D. C. (1995). Speed, stealth, and selective attack: How small firms differ from large firms in competitive behavior. Academy of Management Journal, 38(2), 453-482.

Chen, M.-J., and Su, K.-H., and Tsai, W. (2007). Competitive tension: The Awareness-Motivation-Capability Perspective. Academy of Management Journal, 50(1), 101-118.

Coase, R. H. (1992). The institutional structure of production. The American Economic Review 82(4):713-19.

Collingwood, R. G. (1946). The Idea of History. Oxford: Oxford University Press.

Crossland, Craig, and Donald C Hambrick. 2011. "Differences in managerial discretion across countries: how nation-level institutions affect the degree to which CEOs matter." Strategic Management Journal 32(8):797-819.

David, Paul A. (1994). Why are institutions the "carriers of history'?: Path dependence and the evolution of conventions, organizations and institutions. Structural Change and Economic Dynamics 5(2):205-20.

David, R. J., Sine, W. D., and Haveman, H. A. (2013). Seizing opportunity in emerging fields: How institutional entrepreneurs legitimated the professional form of management consulting. Organization Science, 24(2), 356-377.

Denzau, A. T., \& North, D. C. (1994). Shared mental models: ideologies and institutions. Kyklos, 47(1), 3-31.

Eloranta, J., and Ojala, J. (2005). Converta. In A Finnish Conduit in the East-West Trade. East-West Trade and Cold War, Eloranta, R., Ojala, J. (eds.). Jyväskylä: University of Jyväskylä, 169-198.

Ferrier, W. J. (2001). Navigating the competitive landscape: The drivers and consequences of competitive aggressiveness. Academy of Management Journal, 44(4), 858-877.

Ferrier, W. J., Smith, K. G., and Grimm, C. M. (1999). The role of competitive action in market share erosion and industry dethronement: A study of industry leaders and challengers. Academy of Management Journal, 42(4): 372-388.

Gawande, Kishore, and Usree Bandyopadhyay. (2000). Is protection for sale? Evidence on the Grossman-Helpman theory of endogenous protection. Review of Economics and statistics 82(1):139-52. 
George, E., Chattopadhyay, P., Sitkin, S. B., and Barden, J. (2006). Cognitive underpinnings of institutional persistence and change: A framing perspective. Academy of Management Review, 31(2), 347-365.

Ghosal, V., and Nair-Reichert, U. (2009). Investments in modernization, innovation and gains in productivity: Evidence from firms in the global paper industry. Research Policy, 38(3), 536-547.

Gnyawali, D. R., and Madhavan, R. (2001). Cooperative networks and competitive dynamics: A structural embeddedness perspective. Academy of Management Review, 26(3): 431-445.

Granovetter M. S. 1973. The Strength of Weak Ties. American Journal of Sociology 78(6): 1360-1380.

Granovetter M. S. 1985. Economic Action and Social Structure: The Problem of Embeddedness. American Journal of Sociology 91(3): 481-510.

Greif, A. (1993). Contract enforceability and economic institutions in early trade: The Maghribi traders' coalition. American Economic Review: 92: 525-48.

Greif, A. and Laitin, D. D. (2004). A theory of endogenous institutional change. American Political Science Review 98(04):633-52.

Grimm, C. M., and Smith, K. G. (1997). Strategy as Action: Industry Rivalry and Coordination. Cincinnati: South-Western College Publishing.

Grimm, C. M., Lee, H., and Smith, K. G. (2005). Strategy as Action: Competitive Dynamics and Competitive Advantage. New York: Oxford University Press.

Hambrick, D. C., Cho, T. S., \& Chen, M. J. (1996). The influence of top management team heterogeneity on firms' competitive moves. Administrative Science Quarterly, 42(2): 659-684.

Hart, O. (1995). Firms, Contracts, and Financial Structure. Oxford University Press, London.

Hart, O., and Holmström, B. (1986). The Theory of Contracts: Department of Economics, Massachusetts Institute of Technology.

He, H. (2012). Corporate identity anchors: A managerial cognition perspective. European Journal of Marketing, 46(5), 609-625.

Heikkinen, S. (2000). Paper for the World: The Finnish Paper Mill's Association - Finnpap 1918-1996. Helsinki: Otava.

Helfat, E., and Peteraf, M. A. (2003). The dynamic resource-based view: Capability lifecycles. Strategic Management Journal, 24(10), 997-1010.

Henisz, W. J., and Delios, A. (2000). Learning about the institutional environment. In Ingram, P., and Silverman B. S. (eds.) The New Institutionalism in Strategic Management (Advances in Strategic Management, Volume 19): 339-372.

Hetemäki, L. (2005). Information technology and trends in the paper market. Paper and Timber, 87(7), 424-432.

Hodgson, G. M. 1998. The approach of institutional economics. Journal of Economic Literature 36(1):166-92.

Hope, O-K., Thomas, W., and Vyas, D. (2011). The cost of pride: Why do firms from developing countries bid higher?. Journal of International Business Studies 42(1):128-51.

Ingram, P., and Silverman, B. S. (2000). Introduction: The new institutionalism in strategic management. In Ingram, P., and Silverman B. S. (eds.) The New Institutionalism in Strategic Management (Advances in Strategic Management, Volume 19): 130 .

Jacobides, M. G. (2005). Industry change through vertical disintegration: How and why markets emerged in mortgage banking. Academy of Management Journal, 48(3), 465-498.

Jacobson, R. (1992). The 'Austrian' school of strategy. Academy of Management Review 17(4), 782-807.

Järvinen, J., and Linnakangas, J. (2012). Firm capabilities in the Finnish forest cluster: Comparisons based on self-organizing map. Silva Fennica, 46(1), 131-150.

Järvinen, J., Lamberg, J.-A., and Pietinalho, L. (2012). The fall and the fragmentation of national clusters: Cluster evolution in the paper and pulp industry. Journal of Forest Economics, 18(3), 218-241.

Järvinen, J., Lamberg, J.-A., Murmann, J.-P., and Ojala, J. (2009). Alternative paths to competitive advantage: A fuzzy-set analysis of the origins of large firms. Industry and Innovation, 16(6), 545-574.

Järvinen, J., Lamberg, J.-A., Nokelainen, T., and Tikkanen, H. (2012). Global demand for paper products: 2006-2050. In The Evolution of Global Paper Industry 1800-2050, Lamberg, J.-A., Ojala, J., Peltoniemi, M., Särkkä, T. (eds.). Dordrecht: Springer, 307-343.

Järvinen, J., Ojala, J., Melander, A., and Lamberg, J.-A. (2012). The Evolution of Pulp and Paper Industries in Finland, Sweden, and Norway, 1800-2005. In The Evolution of Global Paper Industry 1800-2050, Lamberg, J.-A., Ojala, J., Peltoniemi, M., Särkkä, T. (eds.). Dordrecht: Springer, 19-47.

Jensen-Eriksen N. (2007a). Läpimurto: Metsäteollisuus Kasvun, Integraation ja Kylmän Sodan Euroopassa 1950-1973. Helsinki: Suomalaisen Kirjallisuuden Seura.

Jensen-Eriksen, N. (2007b). Predators or Patriots? Export cartels as a source of power for the weak. Helsinki University: Working paper.

Jensen-Eriksen, N. (2011). Industrial Diplomacy and Economic Integration: The Origins of All-European Paper Cartels, $1959-72$. Journal of Contemporary History, 46(1), 179-202.

Jensen-Eriksen, N., \& Ojala, J. 2015. Tackling market failure or building a cartel? Creation of an investment regulation system in Finnish forest Industries. Enterprise \& Society, 16(03): 521-555.

Ketchen, D. J., Snow, C. C., Hoover, V. (2004). Research on competitive dynamics: Recent accomplishments and future challenges. Journal of Management, 30(6):779-804.

Ketokivi, M., \& Mahoney, J. (2015). Transaction cost economics as a constructive stakeholder theory. Academy of Management Learning \& Education, amle-2015.

Kipping, M., Wadhwani, R. D., and Bucheli, M. (2014). Analyzing and interpreting historical sources: a basic methodology. Organizations in Time. History, Theory, Methods, 305-329.

Klepper, S., and Thompson, P. (2006). Submarkets and the evolution of market structure. The RAND Journal of Economics, 37(4), $861-886$

Kuisma M. (2008). Kriisi ja Kumous: Metsäteollisuus ja Maailmantalouden Murros 1973-2008. Helsinki: Suomalaisen Kirjallisuuden Seura. 
Lamberg, J.-A., and Laurila, J. (2005). Materializing the societal effect: Organizational forms and changing patterns of dominance in the paper industry. Organization Studies, 26(12): 1809-1830.

Lamberg, J.-A., Tikkanen, H., Nokelainen, T., and Suur-Inkeroinen, H. (2009). Competitive dynamics, strategic consistency, and organizational survival. Strategic Management Journal, 30(1), 45-60.

Langlois, R. N, and Foss, N. J. (1999). Capabilities and governance: the rebirth of production in the theory of economic organization. Kyklos 52(2):201-18.

Langlois, R. N, and Robertson, P. L. (1995). Firms, Markets and Economic Change: A Dynamic Theory of Business Institutions: London: Routledge.

Langlois, R. N. (1986). Rationality, institutions, and explanation. Economics as a process: Essays in the new institutional economics. New York: Cambridge University Press:225-55.

Langlois, R. N. (2013). The Institutional Revolution: A review essay. Review of Austrian Economics, 26(4): 383-395.

Laurila, J., and Ropponen, M. (2003). Institutional conditioning of foreign expansion: Some evidence from Finnish-based paper industry firms, 1994-2000. Journal of Management Studies, 40 (3), 725-751.

Lazonick, W. (1979). Industrial relations and technical change: the case of the self-acting mule. Cambridge Journal of Economics 3(3):231-62.

Le Breton-Miller, I., Miller, D., \& Lester, R. H. (2011). Stewardship or agency? A social embeddedness reconciliation of conduct and performance in public family businesses. Organization Science, 22(3), 704-721.

Levlin, J.-E. (2010). KCL:n vuosikymmenet Otaniemessä, 1962-2009. Espoo: KCL.

Livengood, S. R., and Reger, R. K. (2010). That's our turf! Identify domains and competitive dynamics. Academy of Management Review, 35(1), 48-66.

Mahoney, J., Kimball, E., and Koivu, K. L. (2009). The Logic of Historical Explanation in the Social Sciences. Comparative Political Studies, 42(1), 114-146.

Mantzavinos, C., North, D. C., \& Shariq, S. (2004). Learning, institutions, and economic performance. Perspectives on Politics, 2(01), 75-84.

Markman, G. D., Gianiodis, P. T., and Buchholtz, A. K. (2009). Factor-market rivalry. Academy of Management Review, 34(3), 423441.

Martin, R. (2014). The Past Within Us: An Empirical Approach to Philosophy of History: Princeton University Press.

Meyer, K. E., and Sinani, E. (2009). When and where does foreign direct investment generate positive spillovers: A metaanalysis. Journal of International Business Studies, 40(7), 1075-1094.

Meyer, K.E. (2004). Perspectives on multinational enterprises in emerging economies. Journal of International Business Studies, 35 (4), 259-277.

Miller, D. T., and Prentice, D. A. (1996). The construction of social norms and standards. In Social Psychology: Handbook of Basic Principles, Higgins, E.T., Kruglanski, A.W. (eds.). New York: Guilford.

Miller, D., and Chen, M.-J. (1994). Sources and consequences of competitive inertia: A study of the U.S. airline industry. Administrative Science Quarterly, 39(1), 1-23.

Miller, D., and Chen, M.-J. (1996). Nonconformity in competitive repertoires: A sociological view of markets. Social Forces, 74(4), 1209-1234.

Mintzberg, H. (1978). Patterns in Strategy Formation. Management Science, 24 (9): 934-948.

Mintzberg, H., Raisinghani, D. and Theoret, A. (1976). The Structure of 'Unstructured' Decision Processes. Administrative Science Quarterly 21 (2): 246-275.

Moen, E., and Lilja, K. (2001). Constructing global corporations: Contrasting national legacies in the Nordic forest industry. In The Multinational Firm: Organizing Across Institutional and National Divides, Morgan G., Kristensen, P.H., Whitley, R. (eds.). Oxford: Oxford University Press, 97-121.

Moliterno, T. P., and Wiersema, M. F. (2007). Firm performance, rent appropriation, and the strategic resource divestment capability. Strategic Management Journal, 28(11), 1065-1087.

Mowery, D. C., and D. J. Teece. (1993). Japan's Growing Capabilities in Industrial Technology: Implications for U.S. Managers and Policymakers. California Management Review 35(2):9-34.

Murmann, J. P. (2003). Knowledge and Competitive Advantage: The Coevolution of Firms, Technology, and National Institutions. Cambridge University Press.

Murmann, J. P. (2013). The coevolution of industries and important features of their environments. Organization Science, 24(1), 5878.

Nadkarni, S., and Narayanan, V. K. (2007). Strategic schemas, strategic flexibility, and firm performance: The moderating role of industry clockspeed. Strategic Management Journal, 28(3): 243-270.

Ndofor, H. A., Sirmon, D. G., He, X. (2011). Firm resources, competitive actions and performance: Investigating a mediated model with evidence from the in-vitro diagnostics industry. Strategic Management Journal, 32(6), 640-657.

Nerur, S. P., Rasheed, A. A., \& Natarajan, V. (2008). The intellectual structure of the strategic management field: An author cocitation analysis. Strategic Management Journal, 29(3): 319-336.

Nickerson, J. A., and Silverman, B. S. (2009). New frontiers in strategic management of organizational change. In Nickerson, J. A., Silverman, B. S. (eds.) Economic Institutions of Strategy (Advances in Strategic Management, Volume 26): 525-542.

North, D. C. (1990). Institutions, Institutional Change and Economic Performance. Cambridge University Press, Cambridge.

North, D. C., and Thomas, R. P. (1973). The Rise of the Western World: A New Economic History. Cambridge University Press, Cambridge.

Nykänen, P., and Paulapuro, H. (2005). Telan ympäri: Vuosisata suomalaista paperikone-ja paperinvalmistustekniikkaa. Helsinki: Tekniikan historian seura.

O'Brien, J. P., David, P., Yoshikawa, T., and Delios, A. (2014). How capital structure influences diversification performance: A transaction cost perspective. Strategic Management Journal, 35(7): 1013-1031. 
Ojala, J., Voutilainen, M., and Lamberg, J.-A. (2012). The evolution of the global paper industry: concluding remarks. In The Evolution of Global Paper Industry 1800-2050, Lamberg, J.-A., Ojala, J., Peltoniemi, M., Särkkä, T. (eds.). Dordrecht: Springer, 345-363

Page, S. E. (2006). Path dependence. Quarterly Journal of Political Science,1(1), 87-115.

Page, Scott E. 2006. "Path dependence." Quarterly Journal of Political Science 1(1):87-116.

Parmar, B. L., Freeman, E. R., Harrison, J. S. (2010). Stakeholder theory: The state of art. Academy of Management Annals, 4(1): 403445.

Peltoniemi, M. (2013). Mechanisms of capability evolution in the Finnish forest industry cluster. Journal of Forest Economics, 19(2), 190-205.

Peterson, C. (2001). Finnish engineering and Swedish imperialism: The development paths of two Nordic forest-nations, 1950-1992. Scandinavian Economic History Review, 49(1), 23-40.

Pierson, Paul. (2000). Increasing returns, path dependence, and the study of politics. American Political Science Review 94(02):25167.

Podolny, J. M. (1993). A status-based model of market competition. American Journal of Sociology, 98(4): 829-872.

Porter, M. E. (1980). Competitive Strategy: Techniques for Analyzing Industries and Companies. Free Press, New York.

Porter, M. E. (1996). What is strategy? Harvard Business Review, 45(2).

Pöyry, Jaakko (1979). Suomen metsäteollisuuden kansainvälisen kilpailukyvyn kehittäminen. Helsinki, Jaakko Pöyry Corporation.

Quigley, Timothy J, and Donald C Hambrick. 2015. "Has the "CEO effect" increased in recent decades? A new explanation for the great rise in America's attention to corporate leaders." Strategic Management Journal 36(6):821-30.

Rennel, J. (1984). Future of Paper in the Telematic World. Helsinki: Jaakko Pöyry.

Repenning, N. P., and Sterman, J. D. (2002). Capability traps and self-confirming attribution errors in the dynamics of process improvement. Administrative Science Quarterly, 47(2), 265-2955.

Robertson, P. L., \& Langlois, R. N. (1994). Institutions, inertia and changing industrial leadership. Industrial and Corporate Change, 3(2), 359-378.

Schröter, H. G. (1996). Cartelization and decartelization in Europe, 1870-1995: Rise and decline of an economic institution. Journal of European Economic History, 25(1): 129.

Shaffer, B., Quasney, T. J. and Grimm, C. M. (2000). Firm level performance implications of nonmarket actions. Business \& Society 39(2):126-43.

Smith, K. G., Grimm, C. M., \& Gannon, M. J. (1992). Dynamics of Competitive Strategy. London: Sage.

Smith, K. G., Grimm, C. M., Gannon, M. J., and Chen, M.-J. (1991). Organizational Information Processing, Competitive Responses and Performance in the U.S. Domestic Airline Industry. Academy of Management Journal, 34(1), 60-85.

Suchman, M. C. (1995). Managing legitimacy: Strategic and institutional approaches. Academy of Management Review, 20(3), 571610.

Sydow, Jörg, Georg Schreyögg, and Jochen Koch. 2009. "Organizational path dependence: Opening the black box." Academy of Management Review 34(4):689-709.

Teece, D. (2014). The Foundations of Enterprise Performance: Dynamic and Ordinary Capabilities in an (Economic) Theory of Firms. Academy of Management Perspectives, 28(4): 328-52.

Teece, D. J. (1982). Towards an economic-theory of the multiproduct firm. Journal of Economic Behavior and Organization, 3(1), 3963.

Teece, D. J. (1992). Competition, cooperation and innovation: Organizational arrangements for regimes of rapid technological progress. Journal of Economic Behavior \& Organization 18(1):1-25.

Teece, D. J., Pisano, G., and Shuen, A. (1997). Dynamic capabilities and strategic management. Strategic Management Journal, 18(7), 509-533.

Toivanen, H. (2004). Learning and corporate strategy: The dynamic evolution of the North American pulp and paper industry, 18601960. Doctoral dissertation. Atlanta: Georgia Institute of Technology.

Üsdiken, B., and Kipping, M. (2014). History and organization studies: A long-term view. Organizations in time. History, theory, methods, 33-55.

Vaara, E., and Lamberg, J-A. (2016). Taking historical embeddedness seriously: Three historical approaches to advance strategy process and practice research. Academy of Management Review, 41(4).

Ville, S. (2007). Rent seeking or market strengthening? Industry associations in New Zealand wool broking. Business History Review, 81(2): 297-321.

Wernerfelt, B. (1984). A resource-based view of the firm. Strategic Management Journal, 5(2), 171-180.

Williams, S. D. (2007). Gaining and losing market share and returns: A competitive dynamics model. Journal of Strategic Marketing, 15(2-3): 139-148

Williamson, O. E. (1985). The Economic Institutions of Capitalism. Simon and Schuster; New York.

Williamson, O. E. (1988). Technology and transaction cost economics. Journal of Economic Behavior \& Organization 10(3): $355-63$.

Williamson, O. E. (1991). Strategizing, economizing, and economic organization. Strategic Management Journal, 12(3): 75-94.

Williamson, O. E. (2000). The new institutional economics: taking stock, looking ahead. Journal of Economic Literature, 38(3), 595613.

Williamson, O.E. (1975). Markets and Hierarchies: Analysis and Antitrust Implications. Simon and Schuster, New York.

Winter, S. G. (2006). Toward a neo-Schumpeterian theory of the firm. Industrial and Corporate Change, 15(1), 125-41.

Yu, T., Subramaniam, M., and Cannella, A. A. (2009). Rivalry deterrence in international markets: Contingencies governing the mutual forbearance hypothesis. Academy of Management Journal, 52(1): 127-147.

Zenger, T. R., Lazzarini, S. G., and Poppo, L. (2000). Informal and formal organization in new institutional economics. IncIngram, P., and Silverman B. S. (eds.) The New Institutionalism in Strategic Management (Advances in Strategic Management, Volume 19): 277-305. 
TABLE 1

\section{Description of the Research Phases, Sources, and Objectives}

Phase

Objective

Primary data

Secondary data

Interactions managers and othe industry specialists
Phas

contextualization

Periodization

To acquire an understanding of the dynamics in the institutional and market environment, we engaged in a
synthetizing effort that resulted in a broad synthetizing effort that resulted in a broa

between 1945 and 2000.

Books and articles focusing on economics and the economic history of the forest industry, industry and firm histories, an historical and other studies on international trends in the forest industry.

Statistical information focusing on macrolevel economic and social changes in the forest industry-specific market an institutional environment. At the same time, articles from business magazine that promoted ideas about radical changes in technology and/or business logic were used.

As a part of the larger background project we presented our initial ideas on two occasions to forest industry managers and ex-managers and used the information from these interactions to refine our choice of research period.
Phase 2: External measures

To systematically understand differences and similarities in firm performance and competitive behavior, we engaged in the identification and classification of competitive actions, which resulted in competitive activities of the analyzed firm (in both Finland and the U.S.).

See separate Appendix

See separate Appendix

We presented our initial time series and PCA figures to current and retired executives on multiple occasions within the context of seminars or workshops, and with two executives via email. These interaction verified our choice of measures and the initial interpretation of results.
Phase 3: Analysis of firm-level cognitions and capability evolution (i.e., awareness and capability)

To understand and systematically map the ognitive and capability-related processes potentially explaining realized competitive actions, we engaged in a qualitative analysis of information gathering, filtering, interpretation, and decision-making in Finnish firms.

Strategic planning documents, investment plans, board meeting memos and transcripts, correspondence between corporate correspondence between related archival material.

Business magazines with an emphasis on interviews, local newspapers, and academic research interested in forest industry evolution.

In this phase, we conducted seven interviews (with a former CEO, CFO, strategy officer, R\&D manager, mill manager, and two middlelevel managers) that complemented ou knowledge drawn from archival data and more importantly, helped is interpret our finding and insights.

inten histories, business magazines, company Finnish political and economic history.

Phase 4: Analysis of institutional and governance mechanisms (i.e. motivation)

To study and understand the institutional and governance mechanism, essentially modifying and constraining the motivations preceding competitive actions, we studied the evolution of the institutional structure as a macro phenomenon (i.e., the societal evolution of norms and rules) and the microlevel interpretations of the same norms and rules.

Professional magazines (Paperi and Puu and Talouselämä), board meeting memos, and reports of the Finnish Forest Industry Association (the major special interest group representing forest-industry firms).

During this phase, we engaged in two types of interactions. First, we presented our initial results in two industry-specific workshops and seminars Second, we re-interviewed three informants to better understand the perception of the institutional and governance mechanisms related to the motivation to engage in certain types of activities. 
TABLE 2

The Historical Evolution of Cognitions, Institutions, Governance Structures, and Capabilities in the Finnish Forest

Industry, 1940-2000

\begin{tabular}{|c|c|c|c|c|}
\hline & Managerial cognition & Institutions and governance structure & Capabilities & Main activities \\
\hline $1940 \mathrm{~s}$ & $\begin{array}{l}\text { Firms focus on rebuilding their business } \\
\text { networks after the Second World War }\end{array}$ & $\begin{array}{l}\text { Highly collaborative institutional environment } \\
\text { emphasizing national interests, with no influences or } \\
\text { pressures from abroad }\end{array}$ & $\begin{array}{l}\text { Skills and knowledge focused on low-end } \\
\text { products }\end{array}$ & $\begin{array}{l}\text { First investments in upstream production } \\
\text { capacity }\end{array}$ \\
\hline $1950 \mathrm{~s}$ & $\begin{array}{l}\text { U.S. firms are seen as global leaders of } \\
\text { the industry and thus a target for } \\
\text { imitation }\end{array}$ & $\begin{array}{l}\text { National competitiveness is even more important; } \\
\text { government-supported system to acquire knowledge } \\
\text { about the management of U.S. and Swedish firms }\end{array}$ & $\begin{array}{l}\text { Increasing emphasis on high-end products while } \\
\text { maintaining in-house capabilities, e.g., in } \\
\text { machinery }\end{array}$ & $\begin{array}{l}\text { Adoption of a new technological } \\
\text { generation enabling a large-scale shift to } \\
\text { higher-end products }\end{array}$ \\
\hline $1960 \mathrm{~s}$ & $\begin{array}{l}\text { Globalizing competition is seen as a } \\
\text { threat }\end{array}$ & $\begin{array}{l}\text { The partial liberalization of financial regulation allows } \\
\text { business operations outside the Finnish borders; } \\
\text { collusion is legally accepted and is a norm }\end{array}$ & Highly diversified set of skills and knowledge & First international expansions \\
\hline 1970s & $\begin{array}{l}\text { The global economy is seen as a } \\
\text { problem that affects Finnish firms' } \\
\text { performance }\end{array}$ & $\begin{array}{l}\text { Societal aspects of business and heavy industrial } \\
\text { regulation channel the interests of even the largest } \\
\text { firms }\end{array}$ & $\begin{array}{l}\text { High heterogeneity in skills and knowledge } \\
\text { unrelated to paper and pulp industry }\end{array}$ & Wave of diversification \\
\hline $1980 \mathrm{~s}$ & $\begin{array}{l}\text { Finnish firms are increasingly aware } \\
\text { that they can participate in international } \\
\text { competition }\end{array}$ & $\begin{array}{l}\text { Increasing influence from international business } \\
\text { environment emphasizes the need for firm-specific } \\
\text { strategic agendas }\end{array}$ & $\begin{array}{l}\text { Reduction of skill set in production and } \\
\text { technology and simultaneous built-up of } \\
\text { marketing capabilities }\end{array}$ & $\begin{array}{l}\text { Most investments focus on paper } \\
\text { production technology }\end{array}$ \\
\hline
\end{tabular}


1990s

Firms begin to see global competition as an aggressive matching of dominating U.S. firms

2000s

Firms are first excited to be leading global firms but then become aware that the industry is rapidly eroding
Finnish firms list on foreign stock exchanges and adopt internationally recognized corporate governance practices and management techniques

Market decline and facility closings decrease the institutional power of forest-industry firms, which are increasingly global in terms of practices and norms
Highly focused skill set in paper and paperboard production and sales

A continuing high level of focus on paper and paperboard production with an increasin emphasis on diverse skills and knowledge
Investments in core production facilities continue in the form of mandatory responses to international competition

Divestments of paper-production facilities 
Level

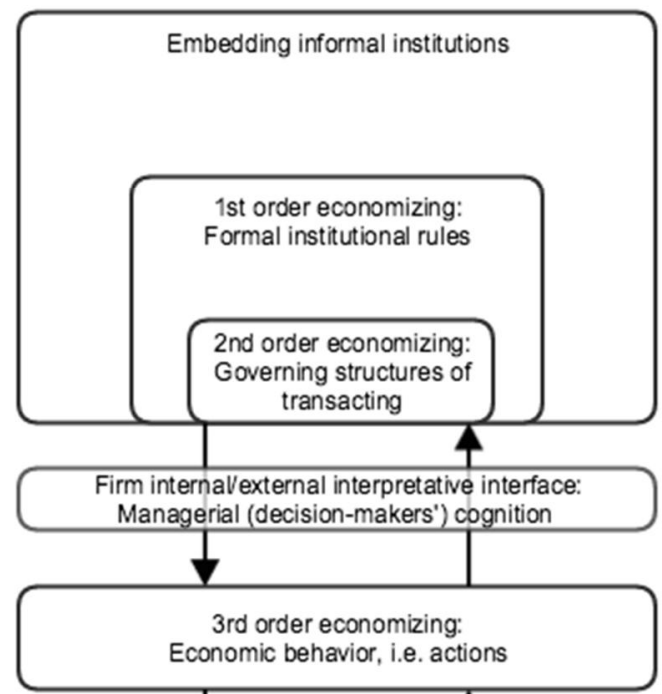

Acquisition and abandonment of capabilities, learning

Capability base enabling and restricting available actions
Purpose

\author{
Often nonspeculative \\ spontaneous \\ Get the institutional \\ environment right \\ Get the govemance \\ structures right
}

Make sense of the environment and determine advantageous and nonadvantageous actions

Carry out those advantageous actions which are possible with available capabilities

Enable current and future actions 
Figure 1: Model of the emergence of competitive actions in their institutional context

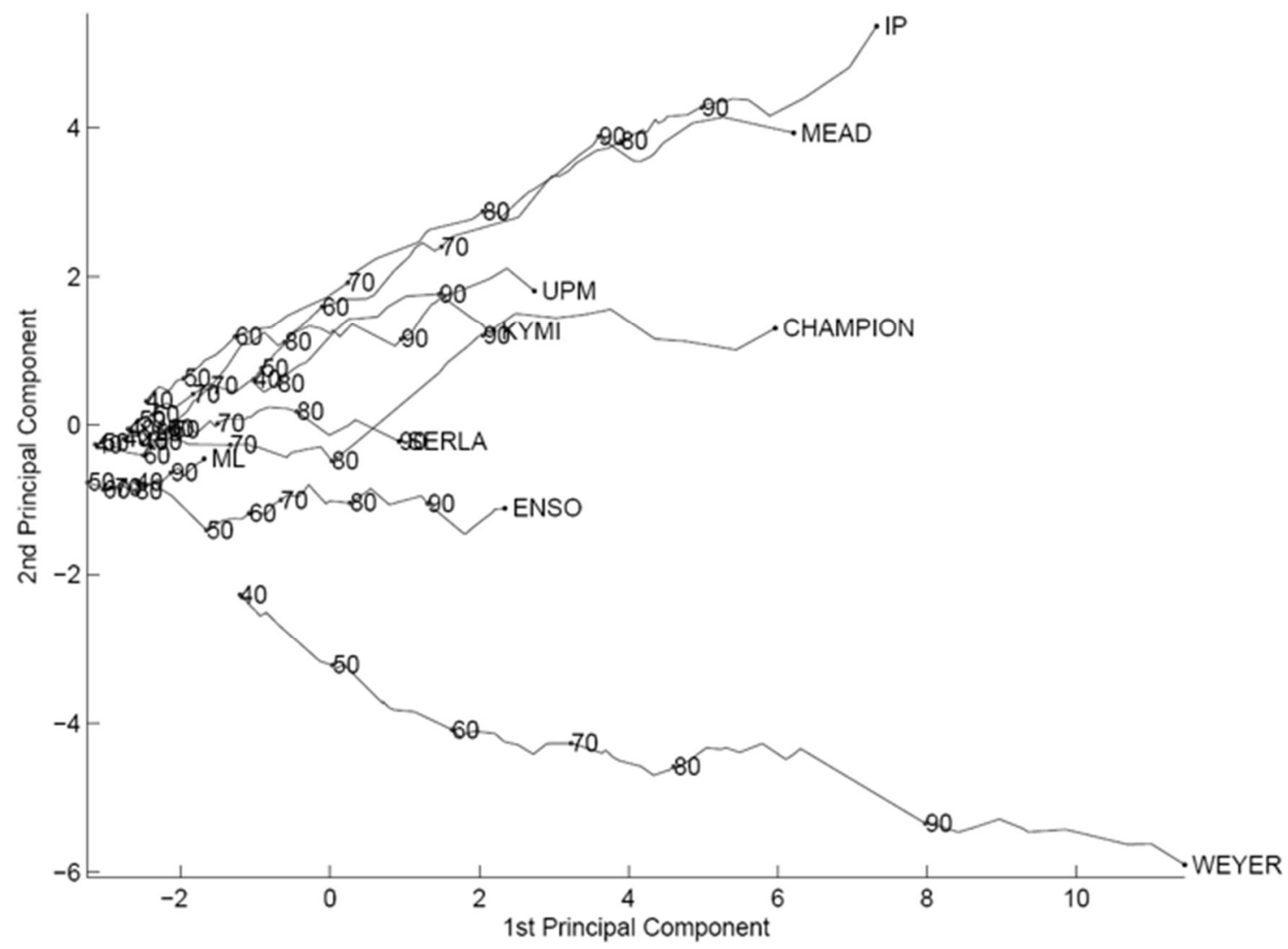

Figure 2. PCA results illustrating the competitive behaviors of the studied companies ${ }^{2}$

${ }^{2}$ IP: International Paper; MEAD: Mead; WEYER: Weyerhaeuser; CHAMPION: Champion; KYMI: Kymi; SERLA: Serlachius; UPM: United Paper Mills; ENSO: Enso-Gutzeit; ML: Metsäliitto. 


\section{Appendix. Description of the Comparative Method}

Our sources for data on the competitive actions of both Finnish and U.S.-based companies for the period of study were Moody's International Industry Manual, company annual reports, company histories (electronic and hard copies), Talouselämä, Business Week, Forbes, the electronic news aggregator Factiva and to some extent, earlier research reports in the cases of Mead, Georgia-Pacific, and Weyerhaeuser (Ahola, 2006) and UPM and Kymi (Ojala, 2006). We relied on prior industry research with regard to the relevant action categories. These categories encompass two types of actions-investments and divestments-in 11 domains of strategic action, yielding a 22-category action typology. This typology is presented in Table 1.

Table 1 (Appendix). Typology of strategic actions employed in the study ${ }^{3}$

\begin{tabular}{|c|c|c|c|}
\hline & & \multicolumn{2}{|c|}{ Mode of action } \\
\hline \multicolumn{2}{|c|}{ Domain of action } & Invest & Divest \\
\hline 1. & Wood and recycled fiber resources & (1) & (2) \\
\hline 2. & Sawn timber and wood products & (3) & (4) \\
\hline 3. & Pulp & (5) & (6) \\
\hline 4. & Paper production & (7) & (8) \\
\hline 5. & Cardboard and containerboard production & (9) & (10) \\
\hline 6. & Sheet products & (11) & (12) \\
\hline 7. & Packaging and converting products & (13) & (14) \\
\hline 8. & Selling and distribution & $(15)$ & (16) \\
\hline 9. & Other related activities & (17) & (18) \\
\hline 10. & Several of the above & (19) & (20) \\
\hline 11. & Unrelated activities & $(21)$ & $(22)$ \\
\hline
\end{tabular}

In identifying and classifying (i.e., coding) the actions into the 22 action categories, we again followed established practices in the empirical research. In the first phase of compiling the action database, two research assistants and two members of the research group were provided with a formal coding manual describing each of the 22 action types. They read the source materials to identify the actions of the sample companies during the period of study. This step resulted in four lists of actions, which were then compared. The final decisions concerning the actions to be included in the analyses were made jointly by the research group. This procedure resulted in 1,378 different actions, which were then coded into the 22 categories, and the results of the independent coding efforts were compared. If disagreements in coding were detected, the research group resolved the discrepancies. No initial action was excluded from the analysis during the coding stage. Table 2 enumerates the number of different actions performed by each company.

Table 2 (Appendix). Number of different types of action performed by each company ${ }^{4}$

\begin{tabular}{|c|c|c|c|c|c|c|c|c|c|c|c|c|}
\hline \multicolumn{13}{|c|}{ Domain of action (mode of action: investment/divestment) } \\
\hline & 1 & 2 & 3 & 4 & 5 & 6 & 7 & 8 & 9 & 10 & 11 & $\Sigma$ \\
\hline INT & $7 / 2$ & $11 / 0$ & $10 / 2$ & $31 / 26$ & $12 / 3$ & $5 / 0$ & $77 / 12$ & $13 / 0$ & $6 / 1$ & $28 / 5$ & $23 / 4$ & $223 / 55$ \\
\hline MEA & $2 / 2$ & $2 / 1$ & $5 / 0$ & $16 / 3$ & $12 / 5$ & $4 / 0$ & $37 / 10$ & $20 / 3$ & $1 / 2$ & $19 / 4$ & $21 / 25$ & $139 / 55$ \\
\hline WEY & $28 / 2$ & $27 / 6$ & $10 / 1$ & $14 / 3$ & $10 / 3$ & $19 / 6$ & $23 / 2$ & $20 / 2$ & $13 / 2$ & $19 / 3$ & $28 / 13$ & $211 / 55$ \\
\hline $\mathrm{CHA}$ & $8 / 12$ & $7 / 6$ & $7 / 0$ & $10 / 3$ & $0 / 3$ & $6 / 2$ & $8 / 4$ & $9 / 2$ & $2 / 0$ & $15 / 11$ & $17 / 8$ & $89 / 43$ \\
\hline KYM & $1 / 1$ & $7 / 2$ & $8 / 2$ & $35 / 6$ & $0 / 1$ & $3 / 1$ & $0 / 2$ & $13 / 2$ & $1 / 0$ & $9 / 2$ & $16 / 12$ & $93 / 31$ \\
\hline
\end{tabular}

${ }^{3}$ Action categories in parentheses.

${ }^{4}$ INT: International Paper; MEA: Mead; WEY: Weyerhaeuser; CHA: Champion; KYM: Kymi; SER: Serlachius; UPM: United Paper Mills; ENS: Enso-Gutzeit; ML: Metsäliitto. 


\begin{tabular}{lccccccccccccc}
\hline SER & $3 / 0$ & $7 / 1$ & $21 / 4$ & $22 / 5$ & $8 / 0$ & $4 / 1$ & $8 / 0$ & $2 / 0$ & $2 / 1$ & $2 / 0$ & $9 / 3$ & $88 / 15$ & $111 / 34$ \\
UPM & $2 / 0$ & $6 / 1$ & $15 / 2$ & $29 / 11$ & $4 / 0$ & $1 / 1$ & $15 / 8$ & $2 / 1$ & $4 / 1$ & $6 / 1$ & $27 / 8$ & $6 / 2$ \\
ENS & $1 / 1$ & $12 / 6$ & $7 / 1$ & $6 / 2$ & $9 / 1$ & $5 / 1$ & $0 / 0$ & $0 / 2$ & $3 / 1$ & $15 / 2$ & $10 / 8$ & $68 / 25$ \\
ML & $4 / 0$ & $6 / 1$ & $4 / 0$ & $9 / 1$ & $1 / 0$ & $2 / 0$ & $5 / 0$ & $3 / 0$ & $0 / 0$ & $10 / 0$ & $0 / 1$ & $44 / 3$ & $1066 / 312$ \\
$\Sigma$ & $56 / 20$ & $85 / 24$ & $87 / 12$ & $172 / 60$ & $56 / 16$ & $49 / 12$ & $173 / 38$ & $82 / 12$ & $32 / 8$ & $123 / 28$ & $151 / 82$ & $(23)$ \\
$(\Sigma \Sigma)$ & $(76)$ & $(109)$ & $(99)$ & $(232)$ & $(72)$ & $(61)$ & $(211)$ & $(94)$ & $(40)$ & $(151)$ & $(233)$ & $(\Sigma \Sigma 1,378)$ \\
\hline
\end{tabular}

After coding, the actions of each company were annually and cumulatively aggregated. Cumulative instead of non-cumulative aggregation is used to emphasize the path-dependence of strategic behavior, which is reminiscent of the paths taken by companies in competitive landscapes (Gavetti and Levinthal, 2000; Siggelkow and Levinthal, 2003). In other words, if a company did not perform any actions in a given year, it preserved its location in the variable space (where the variables are the 22 action categories), and if the company performed certain actions in another year, it "traveled" in the variable space accordingly. To illustrate this movement graphically (Figure 2 below), the variable space had to be reduced to two dimensions (a plane). This dimensional reduction was accomplished through principal component analysis (PCA), which is a computational method that can be used to project multidimensional data onto a lower-dimensional subspace with minimal loss of information (Jolliffe, 1972, 1973). However, PCA loses some information; therefore, we chose to also measure changes in the behaviors of the studied companies with a lossless measure of behavioral consistency. To develop this measure, a company is located somewhere in the 22-dimensional variable space each year based on its past behavior. The actions performed by the company during that year determine whether it moves to a new location in the variable space (if any actions are performed during that year). This travel from a previous location to a new location is represented by a certain distance $d$ (between the two points in the variable space). The direction of this travel has an angular relation (angle $\alpha$ ) to the direction in which the company traveled in the previous year. Thus, a particular point in the variable space has a distance $d$ from the previous point and an angle $\alpha$ between the two vectors points to and from that point. Using these $\mathrm{d}$ and $\alpha$ constructs, we defined behavioral consistency $C$ using Equation 1 .

$$
=\frac{1}{1+\square \square}(0<\square<1)
$$

According to this definition, if a company has made frequent significant changes in its competitive behavior, the measure of behavioral consistency would yield values that are close to zero, whereas if the company has behaved somewhat similarly each year, the measure would yield values that are close to one. After completing the analysis of the strategic actions that enabled a comparison of the behavior of Finnish-based firms to that of their U.S.-based counterparts, we addressed the Finnish firms' managerial perception and interpretation processes along with their institutional underpinnings. The data for the former included material from the archives of individual companies (e.g., minutes of meetings, management memos), coverage by industry-specific journals and other similar outlets, and historical case studies for individual companies. The material for the last category included historical studies of Finnish society in general and the Finnish business system in particular. The analysis of these factors took place in the spirit of a qualitative contextual analysis (Miles and Huberman, 1984). The PCA loadings provide a more detailed indication that travel toward the lower right-hand corner, particularly as exhibited by Weyerhaeuser, is characterized by investments in wood and recycled fiber resources (action type 1), sawed timber and wood products (3), sheet products (11), other related activities (21) and to some extent, investments in selling and distribution (15). Travel toward the higher right-hand corner, exhibited by International Paper and Mead in particular, is characterized not only by investments in packaging and converting products (action type 7) and paper production (4) but also by investments in cardboard and containerboard production (5) and investments that concern several domains simultaneously (10). 